\title{
Self-employment and Entrepreneurship Profile
}

\section{Autoempleo y el Perfil de emprendimiento}

\author{
LIRA-MEJIA, María Carmen \& GARCÍA-SANDOVAL, Evangelina
}

Universidad Tecnológica del Norte de Guanajuato

ID $1^{\text {st }}$ Author: María Carmen, Lira-Mejía / ORC ID: 0000-0002-9520-2929, Researcher ID Thomson: S- 7702-2018, CVU CONACYT ID: 431214

ID $1^{\text {st }}$ Coauthor: Evangelina, García-Sandoval / ORC ID: 0000-0002-5831-0592

DOI: $10.35429 /$ JAF.2019.18.6.1.6

Received March 20, 2019; Accepted June 29, 2019

\begin{abstract}
The current labor market is characterized by its complexity in the lack of sources of formal employment and added to it, the difficulty that young people, women, the disabled, immigrants and all those over 40 have to find a job stable in any part of our society seeing itself in the need of self-employment. Therefore, the self-employed person is the person who has decided to become their own boss, charging for what they work, generating income that goes directly to their pockets, allowing them not to have intermediaries or companies involved in taking their decisions that They allow you to fulfill all the responsibilities that this economic activity implies. Therefore, the purpose of this research is to identify the profile of entrepreneurship in individuals who are self-employed in order to obtain information that allows identifying, understanding and considering some action strategies that may contribute to the strengthening of self-employment in municipalities of San Luis de la Paz, Dolores Hidalgo and San Diego de la Unión belonging to the state of Guanajuato.
\end{abstract}

Self-employment, Business Vision, Business Profile

\begin{abstract}
Resumen
El mercado laboral actual se caracteriza por su complejidad en la falta de fuentes de empleos formales y agregado a ello, la dificultad que tienen los jóvenes, las mujeres, los discapacitados, los inmigrantes y todas aquellas personas mayores de 40 años, para encontrar un empleo estable en cualquier parte de nuestra sociedad viéndose en la necesidad de autoemplearse. Es así como el autoempleado se convierte en la persona que ha decidido ser su propio jefe, cobrando por lo que trabaja, generando ingresos que van directamente a sus bolsillos, permitiéndole no tener intermediarios ni empresas de por medio que intervengan en la toma de sus decisiones, que a su vez le permiten cumplir con todas las responsabilidades que implica ésta actividad económica. La finalidad de la presente investigación, es identificar el perfil de emprendimiento en los individuos que se autoemplean con la finalidad de obtener información que permita identificar, entender y considerar algunas estrategias de acción que puedan contribuir en el fortalecimiento de los autoempleos en los municipios de San Luis de la Paz, Dolores Hidalgo y San Diego de la Unión pertenecientes al estado de Guanajuato.
\end{abstract}

Autoempleo, Visión empresarial, Perfil empresarial

Citation: LIRA-MEJIA, María Carmen \& GARCÍA-SANDOVAL, Evangelina. Self-employment and Entrepreneurship Profile. Journal of Administration and Finance. 2019, 6-18: 1-6

$\dagger$ Researcher contributing first author. 


\section{Introduction}

Self-employment is considered as the work activity created by a person who works for herself, through a business of her own that generates income and that over time, not only created her self-employment and generated profits for herself, but also for more people (The 10 characteristics of the new self-employed, 2019). Therefore, self-employment demands effort and sacrifice, and can be seen as a future challenge in which the self-employed will not only participate with their capital but also with their ingenuity, enthusiasm and potential to develop their own business.

The origin of self-employment has a long historical period that covers many centuries, possibly the people who practiced it did not know that they were self-employed, since there were already tailors, merchants, craftsmen, farmers among many more trades to which they have dedicated.

One of the main reasons that motivate people to self-employment is that they can decide what to do, set their own schedules, live on their passions, allowing them to develop at a professional and personal level, taking on new challenges or simply to obtain greater economic benefits.

The International Labor Organization (ILO) defines self-employment as a sector composed of all those who work in economic units of their own that they manage (Youth, 2019).

Among the work carried out by the state of Guanajuato to promote self-employment are various support programs, another state agency that promotes and promotes this activity is the Secretariat of Agrifood and Rural Development (SDAyR), in one of its publications on the internet reports what next: The SDAyR received 3,754 applications for the rural women, youth self-employment and transformation programs, the representative of the institution highlighted the participation of women, since they made at least 2,976 applications in the municipality of Celaya. The purpose of this is that they can access the programs Boosting Women in the Rural Economy, Youth Self-Employment in the Rural Sector and Promoting the Transformation of Agricultural Production in the Rural Sector.
Likewise, it was pointed out that most of the applications were received for the Rural Women's Economy Boost program, which indicates the interest women have in actively participating in the economic revival of their families and communities. "Only for the Rural Women program, women are interested in undertaking productive projects that generate a very valuable extra income for their families, and at the same time benefit their communities because they bring them products and services, so which becomes a chain of benefits to revive rural areas, "said the state official.

Likewise, the head of the SDAyR informed that 574 applications were received for the Youth Self-Employment program, which provides young people with support in equipment and machinery that allow them to provide services to their communities, whether they are trades or professional services for the case. of young professionals. And for the Agricultural Production Transformation program, 204 applications were received; This aims to provide support for the creation and consolidation of companies in the rural sector (Rural, 2018).

In the present year, 13 property assets were delivered for an amount exceeding 225 thousand pesos to self-employment initiatives and the 2019 Self-Employment Promotion program started in the municipalities of Celaya, Irapuato, Juventino Rosas, Comonfort, Cortazar, Apaseo el Grande and Uriangato. The program is available for the 46 municipalities of the state and for all those who intend to start their own business.

The head of the Ministry of Sustainable Economic Development (SDES), Mauricio Usabiaga Díaz Barriga said that they will be promoted and continue the programs that have been successful, so they will be updated according to current needs. "We see that many programs have been successful in the past, but it is time to renew, it is time to really put the essence, to update us and this is one of the projects that we are really going to benefit, we are not going to put them aside, we want to complement them because we see a lot of future in them, to support everything that they are trades (...), that is what we intend to do, "he said. 
He added that he will work in a coordinated manner with the municipalities, local deputies, senators, society and the private initiative to take advantage of economic development opportunities in Guanajuato. On the other hand, the Undersecretary of Employment and Labor Training, Juan José Álvarez Brunel explained that through the delivery of furniture, equipment and tools, the program 'Fomento al Autoempleo' serves people with the potential to start their own business to generate their own business or allow the consolidation of decent and sustainable jobs. In a first stage, the beneficiaries are given the assets under guarantee, after one year of dedicating themselves to the same activity, they are given ownership of them, he explained.

The 'Self-Employment Promotion' program opens up opportunities for job seekers who have greater difficulties in being hired in the production plant such as: older adults, people with disabilities, entrepreneurs, among others. The objective is to take advantage of the experience acquired in labor practice, so that people who have the ability to transform raw material into finished product and add value can generate their own employment (Sustainable, 2019).

The Federal government and the different instances of the state of Guanajuato through their different support programs boost selfemployment in order to strengthen the economy and reduce unemployment rates. The Mexican Youth Institute (IMJUVE) is an entity of the Federal Government, whose job is to make public policies in favor of Mexican youth to grant them the necessary tools in education, health, employment and social participation (Youth, 2019).

Created in 1999, IMJUVE works for young people by recognizing them with the National Youth Award to those young people who stand out in academia, community work, in human rights or in favor of the environment. Year after year, IMJUVE supports young entrepreneurs with the delivery of financial support to the best business creation projects (Youth, 2019).

\section{Problem Statement}

Despite the efforts, the current labor market is characterized by its complexity in the lack of sources of formal employment and the difficulty of young people, women, the disabled, immigrants, and people over 40 to Find a stable job. Likewise, graduates of universities or students who are still in professional training once they finish their studies, are not able to get a first job opportunity immediately. Given this situation, awareness must be taken of all those involved that self-employment may be an opportunity to develop the knowledge that has been acquired throughout their training, as well as to put into practice the skills obtained to perform a trade, launching a business initiative that can become an important source of job creation in the future.

In the country, the labor market began to be more vulnerable due to the international environment since the 1980s, when the government promoted a series of structural reforms that led to economic liberation and, in turn, flexible labor relations, as well as the reduction of labor market regulations. The main purpose was to achieve greater competitiveness against the international market, however, this soon contributed to the creation of labor inequalities in the country (Sustainable, 2019).

Unemployment is not the only problem that characterizes the Mexican labor market. There are other negative conditions that have been part of it for some time and that seems to accentuate to this day. The transition to the neoliberal model, implanted in the country since the 1980 s, led to the reduction of social security, the cancellation of food price control and transportation, as well as a relaxation of labor legislation (Rural, 2018).

However, despite the efforts made by government institutions to support selfemployment, entrepreneurs are required that the step towards self-employment is not so simple and the difficulties that can be encountered can be many, know each other to himself and knowing that the basic qualities of the entrepreneur are fulfilled, such as passion, perseverance, ingenuity and creativity, is the first step to self-employment. 


\section{Objective}

Identify entrepreneurship profile of people who have generated their own self-employment in the cities of San Luis de la Paz, Dolores Hidalgo and San Diego de la Unión, municipalities of the state of Guanajuato.

\section{Justification}

One of the main reasons for self-employment is to obtain economic benefits, work for oneself and without bosses; Self-employment is a good way out of unemployment and even to develop professionally. A good self-employed person can hire other people to perform complementary tasks to their own, without ever replacing their position.

The self-employed can earn money, obtain an economic benefit and profitability and increase the personal and company assets. It contributes to development in a region and puts into practice its creative and innovative capacity. In another area you can feel self-realized, gain prestige and social recognition.

Likewise, self-employed will work much more than he expected, but a special feature is that he will work for himself and at his own pace. He will be able to develop his abilities and experience with his professional interests and even seeing it from the personal point of view he will have a better balance between his professional and family life, despite working harder, since he will be the one who controls and modulates his work, since it will be his own boss. Although you should never forget that your bosses will be your customers.

Finally, when it is time to retire, it will be the same who decides when to do so, as most people do not retire, "they withdraw".

\section{Methodology}

A conclusive quantitative, qualitative and field investigation was carried out in the cities of San Luis de la Paz, Dolores Hidalgo and San Diego de la Unión, municipalities of the state of Guanajuato. Applying a survey, using the questionnaire as an instrument to a sample of 317 people, with a confidence level of $95 \%$ and an estimation error of $5 \%$, likewise the stratified probabilistic sampling was used, considering the number of inhabitants in each of the locations.

\section{Theoretical framework}

Self-employment implies conducting a business or professional activity at your own risk. Linked directly to this term is the word undertake, which consists of undertaking and starting a work, a business or a project. The union of these two concepts is reflected when we understand SELFEMPLOYMENT as UNDERTAKING an activity carried out on its own, with the final objective of creating a profitable business unit (Professional, 2019).

On the other hand, the business vision is the ability to project the future of a company. It is a statement that indicates where the company is headed in the long term, or what it is that it intends to become in the future. Its importance is that in addition to being a source of inspiration, it also promotes innovative ideas for moments of difficulties (Moreno, 2015).

The business vision can become an innate quality of certain individuals, but many times you have to create it, develop it and for that you have to take into account some characteristics of it (Moreno, 2015):

1. The individual must be clear where he wants to go.

2. When sharing the idea, you should promote the sense of identification and commitment of all members of the company.

3. It must be consistent with the values, principles and culture of the organization.

The business vision is often the promoter of innovative ideas. It is also the one that can sustain companies in times of difficulty. The identification and understanding on the part of everyone involved in the company, is what will make the whole team feel committed to fighting so that the purposes are fulfilled (Moreno, 2015). Likewise, the business profile is one of the most important parts of any business in development. The company profile allows you to announce the details of your services, objectives and experience to potential customers, and is responsible for creating a good first impression to those interested. A business profile can be used on websites or in business directories to help give potential customers a clearer idea of the type of company being managed (Sonia, 2015). 


\section{Results}

According to the results obtained in the field research, the following findings were found: $53 \%$ of the population is female and $47 \%$ is male. Of these $25 \%$ have an age of 16 to 25 years, $25 \%$ of 26 to 35 years, $24 \%$ of 36 to 45 years, $17 \%$ of 46 to 55 years and $9 \%$ are over 56 years.

Regarding the level of education, $27 \%$ have completed high school, $25 \%$ have finished high school, $14 \%$ have completed primary school, $12 \%$ have truncated secondary school, $11 \%$ have truncated secondary school, $6 \%$ have high school High school truncates and 5\% have another type of study level, represented as follows: 55\% study at the university, $20 \%$ do not have studies, $10 \%$ are technical, $10 \%$ do not answer and 5\% are university senior technician.

The place of residence of the respondents, indicates $36 \%$ living in communities, $32 \%$ in colonies, $30 \%$ in municipal headwaters (central areas) and $2 \%$ in other places. According to the results obtained in the field research, the following findings were found: $53 \%$ of the population is female and $47 \%$ is male. Of these $25 \%$ have an age of 16 to 25 years, $25 \%$ of 26 to 35 years, $24 \%$ of 36 to 45 years, $17 \%$ of 46 to 55 years and $9 \%$ are over 56 years.

Regarding the level of education, $27 \%$ have completed high school, $25 \%$ have completed high school, $14 \%$ have completed primary school, $12 \%$ have truncated secondary school, $11 \%$ have truncated secondary school, $6 \%$ have high school High school truncates and $5 \%$ have another type of study level, represented as follows: $55 \%$ study at the university, $20 \%$ do not have studies, $10 \%$ are technical, $10 \%$ do not answer and 5\% are university senior technician They count, 32\% mention that they have another type of business to which they were mentioned, $19 \%$ are dedicated to food, $13 \%$ are resellers of clothing, $10 \%$ sell fried foods, $5 \%$ are fruit sellers, $4 \%$
They are resellers of footwear, $4 \%$ are snow sellers, $4 \%$ are sellers of plants, $4 \%$ are sellers of household appliances, $4 \%$ are sellers of chickpeas and $1 \% \%$ are snow sellers. Considering those who work in other businesses, $20 \%$ have grocery stores, $4 \%$ sell scrapes, $3 \%$ have stationery, 3\% sell mechanical tools, 3\% sell phones, $3 \%$ repair mobile devices, $3 \%$ sell tupperware, $2 \%$ sell balloons, $2 \%$ sell flowers, $2 \%$ sell hamburgers, $2 \%$ sell toys, $2 \%$ have a bakery, $2 \%$ have a music band, $2 \%$ sell juices , $2 \%$ sell perfumes, $2 \%$ sell handicrafts, $2 \%$ do not answer, $1 \%$ have a cyber, $1 \%$ have a laundry, $1 \%$ sell agricultural products, $1 \%$ sell seeds, $1 \%$ have a carnitas stand, $1 \%$ is a hammock seller, $1 \%$ sells pork rinds, $1 \%$ sells seafood, $1 \%$ sells crafts, $1 \%$ sells parts, $1 \%$ sells cakes, $1 \%$ is bolero, $1 \%$ sells corn, $1 \%$ sells ice cream, $1 \%$ sells sweet apples, $1 \%$ repairs shoes, $1 \%$ sells jewelry, $1 \%$ sells tortillas, $1 \%$ is a blacksmith, $1 \%$ is a seller of so Wives, $1 \%$ have a greengrocer, $1 \%$ is a bricklayer, $1 \%$ sells Herbalife, $1 \%$ sells by catalog, $1 \%$ is a merchant, $1 \%$ sells naturopathic medicines, $1 \%$ sells nopales, $1 \%$ sells jellies, $1 \%$ sells smoothies, $1 \%$ sells handbags, $1 \%$ says it is a producer, $1 \%$ is a radio technician, $1 \%$ sells accessories for women, $1 \%$ sells beauty products, $1 \%$ sells medicinal plants, $1 \%$ sells mobile devices, $1 \%$ sells caps, $1 \%$ has an aesthetic, $1 \%$ sells peppers and $1 \%$ has a coffee shop.

The number of employees being the same family members: $88 \%$ have 1 to 3 people, $10 \% 3$ to 5 people and $2 \% 5$ to 10 people (the latter percentage hires people outside the family).

The product is directed according to $81 \%$ of respondents, to the general public, $8 \%$ to young people, $7 \%$ to adults and $4 \%$ to children. Who goes more to buy your product and / or service, $37 \%$ are women, $36 \%$ are children, $18 \%$ are men and $9 \%$ are children.

97\% believe that their business generates profits and 3\% does not.

The reason for self-employment: 59\% like the idea of entrepreneurship, $21 \%$ because the previous job did not allow them to pay their expenses, $12 \%$ because they do not like receiving orders and $8 \%$ for another reason, which indicate $17 \%$ have not found a good job, $17 \%$ for having extra earnings. 
$17 \%$ for necessity, $13 \%$ because it is a family inherited business, $8 \%$ for helping the family, $8 \%$ for family reasons, $4 \%$ for having a truncated education, $4 \%$ for all those mentioned in the question (likes to undertake, does not want to receive orders and wants extra income), $4 \%$ for disability and $4 \%$ for dismissal.

92\% would like their business, pointing out: $42 \%$ having more customers, $37 \%$ with a larger establishment, $18 \%$ with more equipment and $3 \%$ with other support, that is $43 \%$ with more team and a larger establishment, $38 \%$ with a local, $10 \%$ with more equipment, larger establishment and with an increase in its customers, $7 \%$ with more product and $2 \%$ with all those indicated. And $8 \%$ would not like to grow.

\section{Conclusions}

Nowadays there are more and more selfemployed people although with low salaries. Companies have increased their levels of productivity and the use of technology, which has led to the dismissal of workers who in turn have dedicated themselves to seeking employment options.

The existence of programs that have launched the different levels of government to combat the problem of lack of employment in Mexico, have provided economic support and training to develop self-employment, considering the potential and level of importance in the economy of families and therefore in society.

With the results obtained, the following profile can be identified in the self-employed: the number of employees who support the selfemployed is 3 people, their market is the general public, however women and children go to establishments more frequently. He has been motivated by the pleasure to undertake, because he has not found a good job, he wants to have extra earnings and out of necessity. In your business vision you would like your business to grow, having more customers, with a larger establishment and with more equipment to work.
It is important to highlight that young people can develop in their own municipalities and not everyone has to emigrate to the big cities, since they generally self-employ, considering the areas of opportunity they observe in their own communities or municipalities, thus creating sources of employment in each region.

\section{References}

Empleo. (26 de mayo de 2019). Las 10 características del nuevo autoempleado. Obtenido de http:www.autoempleo.net/Articulos/

Entrepreneur. (26 de febrero de 2015). Obtenido de 50 razones para iniciar tu propio negocio: https://www.entrepreneur.com/article/267925

Juventud, I. M. (2019). Prensa. Obtenido de https://www.gob.mx/imjuve/que-hacemos

Moreno, I. (11 de noviembre de 2015). Visión Empresarial. Obtenido de https://www.impulsapopular.com/gerencia/elpoder-de-una-vision-empresarial-constituida/

Profesional, R. d. (02 de septiembre de 2019). El autoempleo. Obtenido de https://www.navarra.es/home_es/Temas/Emple $\mathrm{o}+\mathrm{y}+$ Economia/Empleo/Empleo/Orientacion $+\mathrm{L}$ aboral/riiopn/home/Trabajar/AutoEmpleo/QueE sAutoEmpleo.htm

Rural, S. d. (19 de febrero de 2018). Boletines Guanajuato. Obtenido de https://boletines.guanajuato.gob.mx/2018/02/19 /recibe-sdayr-3-mil-754-solicitudes-de-apoyopara-programas-mujer-rural-autoempleojuvenil-y-transformacion/

Sonia. (1 de septiembre de 2015). Blogs de Emprendedores. Obtenido de http://www.estartap.com/como-crear-un-perfilempresarial/

Sustentable, S. d. (16 de enero de 2019). Boletínes Guanajuato. Obtenido de https://boletines.guanajuato.gob.mx/2019/01/16 /arranca-programa-fomento-al-autoempleo2019/ 